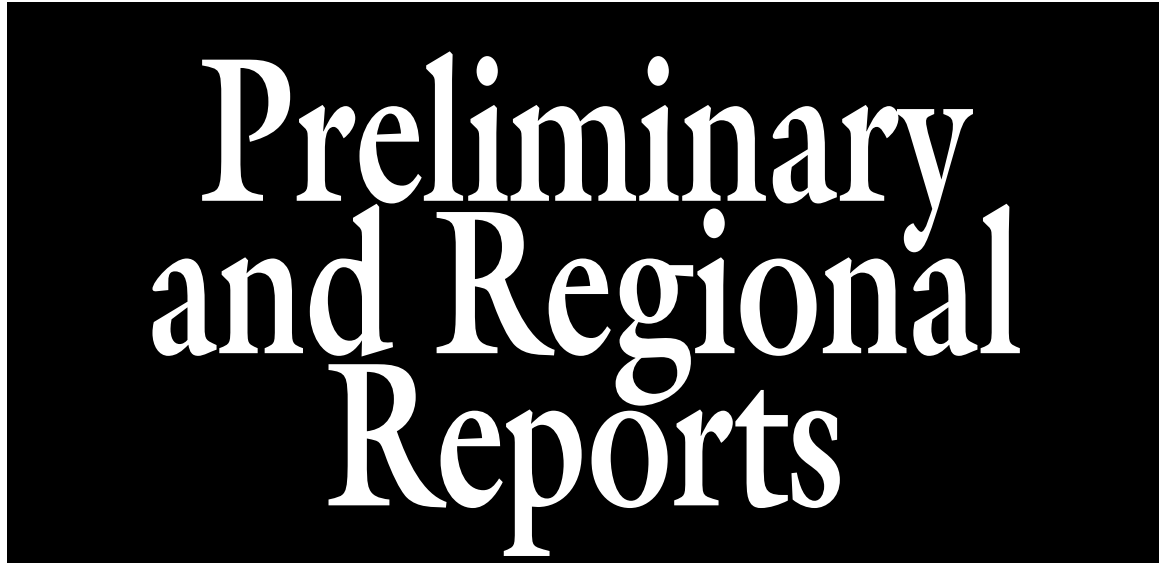

\title{
Physical Characteristics of and Seed Germination in Commercial Green Roof Substrates
}

\author{
Derald A. Harp ${ }^{1}$, Cheng Chen, and Curtis Jones
}

Additional Index words. Gaillardia pulchella, Achillea millefolium, Phaseolus vulgaris, Leucanthemum $\times$ superbum, expanded shale

$\overline{\text { SUMMARY. Green roofs provide multiple environmental and economic benefits, such as }}$ roof surface temperature reduction, reduced internal cooling needs, storm water management, and extended life span of roofing materials. However, green roof substrates must be relatively lightweight, so it is typically coarse with limited water holding capacity. We hypothesize the physical characteristics that make the substrates successful on a roof are likely to reduce seed germination. For this study, we tested the germination of three perennial species and one annual: shasta daisy (Leucanthemum $\times$ superbum), yarrow (Achillea millefolium), and indian blanket (Gaillardia pulchella), and pinto bean (Phaseolus vulgaris) (as a control) across five different substrates: peat/ perlite/large expanded shale, compost/sand/expanded shale, compost/black dirt/ expanded shale, compost/expanded shale, and peat/perlite (control). Substrate physical and chemical properties were analyzed, and a germination test conducted using a randomized complete block design, with each species/substrate combination appearing once per block. Germination was defined as seedling emergence, and monitored every 7 days for 28 days. Pinto bean had the highest germination $(76.2 \%)$ across all substrates, compared with $\mathbf{4 3 . 4 \%}$ for indian blanket, $\mathbf{4 0 . 4 \%}$ for yarrow, and $\mathbf{2 3 . 0 \%}$ for shasta daisy. Seed germination, across all species, was lower in green roof substrates. Germination success was very strongly correlated with seed length, seed width, and seed area, while no relationship was found between seed germination and substrate $\mathrm{pH}$ or electrical conductivity (EC). Therefore, it is likely that the physical characteristics of green roof substrates create poor conditions for seed germination.

G reen roofs provide many environmental benefits; primary among these is the cooling of urban surfaces, and also play important roles in storm water runoff quantity and quality, increased life span of roofing membranes, mitigation of urban heat islands, increased biodiversity, improved aesthetic value, improved air quality, and noise reduction (Getter

Department of Agricultural Sciences, Texas A\&M University-Commerce, P.O. Box 3011, Commerce, TX 75429

We thank Jim Heitholt and David Zlesak for their valued assistance with this project.

${ }^{1}$ Corresponding author. E-mail: derald.harp@tamuc.edu. and Rowe, 2006; Oberndorfer et al., 2007; U.S. Environmental Protection Agency, 2008). Cooling comes from the interception of incoming solar radiation by plants and soil, and the use of excess energy for evapotranspiration (Young et al., 2014). This reduces roof surface temperatures by 25 ${ }^{\circ} \mathrm{C}$ or more (Harp and Dunlap, 2012; Liu and Minor, 2005). Reduced surface temperatures decrease heat load on the building and lower internal building temperatures, reducing load on climate control systems and decreasing energy usage (Castleton et al., 2010; Niachou et al., 2001; Santamouris et al., 2007). However, this effect is contingent on vegetation as energy reflection increases by roughly $5 \%$ (MacIvor and Lundholm, 2011) and evapotranspiration from $10 \%$ to $50 \%$ when compared with unvegetated substrate surfaces (Voyde et al., 2010; Young et al., 2014). The related surface temperature changes are significant, with bare substrate surface temperatures $16{ }^{\circ} \mathrm{C}$ warmer than vegetated surfaces (Harp and Dunlap, 2012).

Green roof substrates are designed to provide the necessary physical support, water, and nutrients to plants, while maintaining the proper amount of aeration and drainage to prevent the excess accumulation of water, possibly leading to substrate weight exceeding building design specifications (Ampim et al., 2010; Young et al., 2014). Substrates typically include a coarse aggregate (crushed brick, expanded shale) and organic matter (compost or peatmoss), with organic matter composing $10 \%$ to $20 \%$ of the substrate volume (Ampim et al., 2010; Olszewski et al., 2010). Recent studies have included the use of hydrophilic polymers to increase plant available water in the substrate (Olszewski et al., 2010; Young et al., 2014).

Plant establishment in green roofs is generally from transplant of liners or plugs. However, plant population maintenance, especially for annuals and short-lived perennials, relies on either replanting or the success and growth of

\begin{tabular}{llll}
\hline $\begin{array}{l}\text { Units } \\
\begin{array}{l}\text { To convert U.S. to SI, } \\
\text { multiply by }\end{array}\end{array}$ & U.S. unit & SI unit & $\begin{array}{l}\text { To convert SI to U.S., } \\
\text { multiply by }\end{array}$ \\
\hline 29.5735 & $\mathrm{fl} \mathrm{oz}$ & $\mathrm{mL}$ & 0.0338 \\
0.0929 & $\mathrm{ft}^{2}$ & $\mathrm{~m}^{2}$ & 10.7639 \\
2.54 & inch(es) & $\mathrm{cm}$ & 0.3937 \\
25.4 & inch $(\mathrm{es})$ & $\mathrm{mm}$ & 0.0394 \\
645.1600 & inch & $\mathrm{mm}^{2}$ & 0.0016 \\
1 & micron $(\mathrm{s})$ & $\mu \mathrm{m}^{2}$ & 1 \\
1 & $\mathrm{mmho} / \mathrm{cm}$ & $\mathrm{mS} \cdot \mathrm{cm}^{-1}$ & 1 \\
28.3495 & $\mathrm{oz}$ & $\mathrm{g}$ & 0.0353 \\
1.7300 & $\mathrm{oz} / \mathrm{inch}^{3}$ & $\mathrm{~g} \cdot \mathrm{cm}^{-3}$ & 0.5780 \\
$\left({ }^{\circ} \mathrm{F}-32\right) \div 1.8$ & ${ }^{\circ} \mathrm{F}$ & ${ }^{\circ} \mathrm{C}$ & $\left({ }^{\circ} \mathrm{C} \times 1.8\right)+32$
\end{tabular}

Hortlechnology $\cdot$ April 2015 25(2) 
seeds. Ksiasek et al. (2014) confirmed that green roof plants are capable of producing viable seed. However, few plants produce successful seedlings (Hopman, 2011). Planting from seed is also considerably cheaper, with an estimated cost of about $\$ 54 / \mathrm{m}^{2}$ when direct planting stonecrop ( $\mathrm{Se}$ dum sp.) vs. $\$ 8.50 / \mathrm{m}^{2}$ for comparable grass cover from seed (Sutton, 2013). Unfortunately, plant establishment from seeding is generally poor unless special techniques, such as hydromulch, are used (McDavid, 2012).

Seed germination requires an optimal range of environmental conditions, primarily concerning temperature and water availability, for germination. Substrates must ensure good seed-to-soil contact to avoid wide fluctuating wet-dry cycles (U.S. Department of Agriculture, 2005). In peat-based substrates, water content is very high (generally in excess of $65 \%$ at container capacity) and air-filled pores are typically under $20 \%$ (Nelson, 2003). In contrast, ideal green roof substrates have water content by volume of $40 \%$ or less and $20 \%$ or more air-filled pores (Ampim et al., 2010; Harp et al., 2008).

A previous trial by D.A. Harp and C. Dunlap (unpublished data) unsuccessfully attempted to germinate indian blanket seeds on a north Texas green roof. Others, including Hopman (2011) identified many species that perform well in north Texas green roofs, but only one, prairie tea (Croton monanthogynus), successfully reseeds. McDavid (2012) only achieved successful germination in green roof substrates when seeds were held in a hydromulch substrate. It is likely that the low germination success is due to the characteristics of the green roof substrates, as this is repeated across different species but similar substrates. Therefore, this study was conducted to evaluate seed germination of herbaceous perennial species commonly used as green roof plants in commercial green roof substrates.

\section{Materials and methods}

Substrates analysis. Four green roof substrates and a peat/perlite growing substrates were obtained from commercial sources (Table 1 ). Before initiation of the germination study, three subsamples of each substrate were sent to the Horticultural Substrates Testing Laboratory (North
Carolina State University, Raleigh) for determination of physical characteristics, including total porosity, water holding capacity [water-filled pores at container capacity (WFP)], air space [air-filled pores at container capacity (AFP)], and bulk density $\left(D_{\mathrm{b}}\right)$ (Fonteno and Harden, 2003). Three subsamples from each substrate were analyzed for $\mathrm{pH}$ and $\mathrm{EC}$ in the Texas A\&M University-Commerce plant science

research laboratory using the pourthrough extraction procedure (Wright, 1986).

Particle size analysis of substrate samples were conducted locally via sieve separation. Substrate samples were dried at $37^{\circ} \mathrm{C}$ for $24 \mathrm{~h}$. Dried substrates were divided into three 100-g samples. Each sample was shaken, by hand, through a series of five sieves (screen openings of 4,2 ,

Table 1. Green roof and horticultural growing substrates from commercial sources used to assess seed germination in green roof substrates vs. a peat-lite substrate.

\begin{tabular}{|c|c|c|}
\hline $\begin{array}{l}\text { Growing } \\
\text { substrate }\end{array}$ & Source & Major components \\
\hline GRl & Weston Solutions, Chicago, IL & Peat, perlite, expanded shale ${ }^{z}$ \\
\hline GR2 & Soil Building Systems, Dallas, TX & Compost, sand, expanded shale \\
\hline GR3 & Soil Building Systems & $\begin{array}{l}\text { Compost, black dirt, expanded } \\
\text { shale }^{\mathrm{y}}\end{array}$ \\
\hline GR4 & Landscapers Pride, New Waverly, TX & Compost, expanded shale \\
\hline BM6 & $\begin{array}{l}\text { Berger Horticultural Products, } \\
\text { Saint-Modeste, Quebec, Canada }\end{array}$ & Peat, perlite \\
\hline
\end{tabular}

${ }^{\text {z}}$ Observed only; no manufacturer's information available.

ySubstrate for experimental use only and described using manufacturer's terminology.

Table 2. Comparison of particle size distribution in commercially available green roof and horticultural growing substrates as determined using wire mesh sieves and shaken by hand for $3 \mathrm{~min}$.

\begin{tabular}{lrrrrrc}
\hline & \multicolumn{5}{c}{ Proportion of substrate by wt $(\%)$ by particle diam $(\mathbf{m m})^{\mathrm{y}}$} \\
\cline { 2 - 7 } Substrates $^{\mathbf{z}}$ & $\mathbf{> 4}$ & $\mathbf{2 - 4}$ & $\mathbf{0 . 5}-\mathbf{2}$ & $\mathbf{0 . 1 3 - 0 . 5}$ & $\mathbf{0 . 0 6}-\mathbf{0 . 1 3}$ & $<\mathbf{0 . 0 6}$ \\
\hline GR1 & 62.6 & 18.9 & 10.3 & 4.3 & 1.2 & 2.7 \\
GR2 & 63.6 & 15.4 & 4.7 & 7.7 & 5.1 & 3.5 \\
GR3 & 61.7 & 26.5 & 6.8 & 3.5 & 0.8 & 0.7 \\
GR4 & 23.8 & 29.2 & 32.1 & 9.1 & 2.2 & 3.6 \\
BM6 & 5.8 & 16.7 & 56.2 & 17.7 & 3.0 & 0.6
\end{tabular}

${ }^{\mathrm{z}} \mathrm{GRl}=$ Green Grid Roof growth substrates (Weston Solutions, Chicago, IL); GR2 = Green Roof Mix (Soil Building Systems, Dallas, TX); GR3 = Experimental Green Roof Mix (Soil Building Systems); GR4 = Rooflite Extensive Green Roof Mix (Landscapers Pride, New Waverly, TX); and BM6 = BM6 (Berger Horticultural Products, Saint-Modeste, Quebec, Canada).

$\mathrm{y} 1 \mathrm{~mm}=0.0394$ inch

Table 3. Comparison of commercially available green roof substrates and a peatlite substrate physical properties, as analyzed by Horticultural Substrates Laboratory at North Carolina State University.

\begin{tabular}{lccccc}
\hline Porosity & $\begin{array}{c}\text { Water-filled } \\
\text { pores } \\
\text { Substrate }\end{array}$ & $\begin{array}{c}\text { Air-filled } \\
\text { pores } \\
(\% \text { volume })\end{array}$ & $\begin{array}{c}\text { WFP:AFP } \\
(\text { volume })\end{array}$ & $\begin{array}{c}\text { Bulk density } \\
\left(\mathbf{g} \cdot \mathbf{c m}^{-3}\right)^{\mathbf{x}}\end{array}$ \\
\hline GR1 & $69.0 \mathrm{~b}^{\mathrm{w}}$ & $39.6 \mathrm{c}$ & $29.4 \mathrm{a}$ & $1.35 \mathrm{c}$ & $0.54 \mathrm{c}$ \\
$\mathrm{GR} 2$ & $66.5 \mathrm{~b}$ & $34.4 \mathrm{c}$ & $32.1 \mathrm{a}$ & $1.07 \mathrm{c}$ & $0.82 \mathrm{a}$ \\
GR3 & $66.8 \mathrm{~b}$ & $35.1 \mathrm{c}$ & $31.8 \mathrm{a}$ & $1.11 \mathrm{c}$ & $0.79 \mathrm{a}$ \\
GR4 & $63.2 \mathrm{c}$ & $44.8 \mathrm{~b}$ & $18.4 \mathrm{~b}$ & $2.44 \mathrm{~b}$ & $0.64 \mathrm{~b}$ \\
BM6 & $85.5 \mathrm{a}$ & $71.9 \mathrm{a}$ & $13.6 \mathrm{c}$ & $5.38 \mathrm{a}$ & $0.16 \mathrm{~d}$ \\
\hline
\end{tabular}

${ }^{{ }^{z} \mathrm{GRl}}=$ Green Grid Roof growth substrates (Weston Solutions, Chicago, IL); GR2 = Green Roof Mix (Soil Building Systems, Dallas, TX); GR3 = Experimental Green Roof Mix (Soil Building Systems); GR4 = Rooflite Extensive Green Roof Mix (Landscapers Pride, New Waverly, TX); and BM6 = BM6 (Berger Horticultural Products, Saint-Modeste, Quebec, Canada).

Whater-filled pores:air-filled pores.

${ }^{\mathrm{x}} \mathrm{l} \mathrm{g} \cdot \mathrm{cm}^{-3}=0.5780 \mathrm{oz} /$ inch $^{3}$.

wWithin columns, means followed by the same letters are not significantly different at $P<0.05$ using Duncan's multiple range test. 
$0.5,0.125$, and $0.0625 \mathrm{~mm}$ ) for $3 \mathrm{~min}$. Substrate material retained on each sieve was measured to the nearest $0.1 \mathrm{~g}$ and converted to volumetric measures by multiplying with the $D_{\mathrm{b}}$.

Seed germination. Before initiation of the substrates study, a germination test was used to determine seed quality. Four replicates of 25 seeds from each species were placed in a $20 \times 100$-mm plastic petri dish with two Whatman No. I filter paper (Whatman, Kent, U.K.). Each dish was irrigated with $\approx 10 \mathrm{~mL}$ water to saturate the germination blotters. Seeds were placed in natural, indirect light at room temperature $\left(22{ }^{\circ} \mathrm{C}\right)$, and germination measured weekly for 4 weeks. Blotters were irrigated on an as-needed basis to maintain adequate moisture, and radicle emergence was used to indicate germination. A minimum germination percentage of 85 was required for the seeds to continue into the main study.

Four green roof substrates and a peat-lite substrate were used to fill $10 \times 20$-inch germination trays to a depth of 2 inches arranged in a randomized complete block design with four blocks and each growing substrates appearing once per block. Each germination tray was separated into five growing areas, one per species tested and one open, each $\approx 4 \times$ 10 -inches. Twenty-five seeds from each species were assigned randomly to one section of the germination tray and treated as an experimental unit. This design ensured that each seed/ substrate combination was replicated once in each block.

Trays were placed in the greenhouse during Apr. 2013 and monitored daily for 6 weeks. Trays were watered on alternate days to ensure adequate moisture, and rated for germination every $7 \mathrm{~d}$, with germination defined as shoot emergence. Germinated seedlings were removed after scoring to prevent competition.

STATISTICAL anAlysis. Proc GLIMMIX (SAS version 9.3; SAS Institute, Cary, NC) was used to compare germination percentage at each recording interval and germination rate across species and substrates types. Arcsine square root transformations were made on all germination percentages before analysis and back transformed for presentation purposes. Comparisons included any possible interactions between species and substrate. Means were separated using least square means with the DIFF LINES option to generate pairwise comparison of means. Substrate characteristics were compared using Proc ANOVA (SAS version 9.3), and means were separated using Duncan's multiple range test. Proc CORR was used to ascertain relationships between $\mathrm{pH}, \mathrm{EC}, \mathrm{WFP}, \mathrm{AFP}, \mathrm{WFP}$ :AFP ratio, $D_{\mathrm{b}}$, seed size, and germination success.

\section{Results}

Particle size distribution. Large particles dominated substrates GR1, GR2, and GR3, the majority of which were expanded shale. By weight, over $60 \%$ of these substrates were composed of particles $4 \mathrm{~mm}$ in diameter or larger $(62.6 \%, 63.6 \%$, and $61.7 \%$, respectively). GR1, GR2, and GR3 were also similar in that over $79 \%$ of their particles were $>2 \mathrm{~mm}$ $(81.5 \%, 79.0 \%$, and $88.2 \%$, respectively) (Table 2). In these three substrates, only $10.3 \%, 4.7 \%$, and $6.8 \%$, respectively, of particles were between 0.5 and $2 \mathrm{~mm}$ in diameter (Table 2).

The particle size distribution of GR4 was unique among the green roof substrates, a smaller percentage $(23.8 \%)$ of its particles were $>4 \mathrm{~mm}$. Similar to other green roof substrates, $85.1 \%$ of its particles were $0.50 \mathrm{~mm}$ consistent with the other three green roof substrates. Although the largest particles were smaller, it had more particles in the 2 to $4 \mathrm{~mm}$ and 0.50 to $2 \mathrm{~mm}$ size ranges (Table 2 ). It is important to note that GR4 was a mix of only compost and expanded shale.

The majority of particles in the peat-lite control were in the 0.5 to diameter or larger. This distribution is

$2 \mathrm{~mm}$ range. Only $5.8 \%$ of the mix included particles $>4 \mathrm{~mm}$ in diameter, and less than $17 \%$ were $>2 \mathrm{~mm}$ in diameter. Drzal et al. (1999) notes that medium-sized particles $(0.5$ to $2 \mathrm{~mm}$ ) in green roof substrates contribute positively to the substrate water holding capacity, air space, total porosity, and plant available water.

Physical properties. As expected, the variation in particle size distribution likely contributed to considerable changes in the physical properties of the various substrates tested. The peat-lite mix had much higher total porosity [TP $(85.5 \%)]$ and WFP $(71.8 \%)$ than all four of the green roof substrates, with comparable decreases in AFP (13.6\%) and $D_{\mathrm{b}}\left(0.16 \mathrm{~g} \cdot \mathrm{cm}^{-3}\right)($ Table 3$)$.

Physical properties were similar across the various green roof substrates.

Table 4. Average $\mathrm{pH}$ and electrical conductivity (EC) of four commercially available green roof substrates and a peat-lite substrate determined using the pour-through extraction method (Wright, 1986).

\begin{tabular}{lcc}
\hline Substrate & pH & EC $\left(\mathrm{mS} \cdot \mathrm{cm}^{-1}\right)^{\mathrm{x}}$ \\
\hline GR1 $^{\mathrm{z}}$ & $8.0 \mathrm{a}^{\mathrm{y}}$ & $0.37 \mathrm{c}$ \\
GR2 & $8.1 \mathrm{a}$ & $0.34 \mathrm{c}$ \\
GR3 & $8.1 \mathrm{a}$ & $4.44 \mathrm{a}$ \\
GR4 & $7.9 \mathrm{~b}$ & $0.56 \mathrm{c}$ \\
BM6 & $6.7 \mathrm{c}$ & $1.47 \mathrm{~b}$ \\
\hline
\end{tabular}

${ }^{\mathrm{z}} \mathrm{GRl}=$ Green Grid Roof growth substrates (Weston Solutions, Chicago, IL); GR2 = Green Roof Mix (Soil Building Systems, Dallas, TX); GR3 = Experimental Green Roof Mix (Soil Building Systems); GR4 = Rooflite Extensive Green Roof Mix (Landscapers Pride, New Waverly, TX); and BM6 = BM6 (Berger Horticultural Products, Saint-Modeste, Quebec, Canada).

$\mathrm{y} 1 \mathrm{mS} \cdot \mathrm{cm}^{-1}=1 \mathrm{mmho} / \mathrm{cm}$

${ }^{x}$ Within columns, means followed by the same letters are not significantly different at $P<0.05$ using Duncan's multiple range test.

Table 5. Comparison of seed germination for three perennial flowers to pinto bean in four commercially available green roof substrates and a peat-lite substrate.

\begin{tabular}{lccccc}
\hline & \multicolumn{5}{c}{ Germination (\%) } \\
\cline { 2 - 6 } Substrate $^{\mathrm{z}}$ & Pinto bean Indian blanket & Yarrow & Shasta daisy Avg by substrate \\
\hline GR1 & 78 & 39 & 38 & 21 & $44.0 \mathrm{~b}^{\mathrm{x}}$ \\
GR2 & 69 & 39 & 34 & 15 & $39.3 \mathrm{~d}$ \\
GR3 & 70 & 36 & 30 & 14 & $37.5 \mathrm{~d}$ \\
GR4 & 67 & 40 & 36 & 15 & $39.5 \mathrm{c}$ \\
BM6 & 97 & 63 & 64 & 50 & $68.5 \mathrm{a}$ \\
Avg by species & $76.2 \mathrm{a}^{\mathrm{y}}$ & $43.4 \mathrm{~b}$ & $40.4 \mathrm{~b}$ & $23.0 \mathrm{c}$ & \\
\hline
\end{tabular}

${ }^{\mathrm{z}} \mathrm{GRl}=$ Green Grid Roof growth substrates (Weston Solutions, Chicago, IL); GR2 = Green Roof Mix (Soil Building Systems, Dallas, TX); GR3 = Experimental Green Roof Mix (Soil Building Systems); GR4 = Rooflite Extensive Green Roof Mix (Landscapers Pride, New Waverly, TX); and BM6 = BM6 (Berger Horticultural Products, Saint-Modeste, Quebec, Canada).

${ }^{y}$ Within the row, means followed by the same letters are not significantly different at $P<0.05$ using Duncan's multiple range test (DMRT).

${ }^{x}$ Within the column, means followed by the same letters are not significantly different at $P<0.05$ using DMRT. 
GRl, GR2, and GR3 had similar TP $69.1 \%, 66.5 \%$, and $66.8 \%$, respectively), WFP $(39.6 \%, 34.3 \%$, and $35.1 \%$, respectively), and AFP $(29.4 \%$, $32.1 \%$, and $31.8 \%$, respectively) (Table $3)$. GRl had the lowest $D_{\mathrm{b}}$ among green roof substrates $\left(0.54 \mathrm{~g} \cdot \mathrm{cm}^{-3}\right)$ and GR2 had the highest $\left(0.82 \mathrm{~g} \cdot \mathrm{cm}^{-3}\right)$. GR4 was intermediate to other tested substrates with a TP of $63.2 \%$, a WFP of $44.8 \%$, an AFP of $18.4 \%$, and a $D_{\mathrm{b}}$ of $0.64 \mathrm{~g} \cdot \mathrm{cm}^{-3}$.

Chemical properties. Green roof mixes were remarkably similar, with the exception of elevated EC in GR2, but notably different from the peat-lite substrate. The $\mathrm{pH}$ of green roof substrates was mildly to moderately alkaline, ranging from 7.8 in GR4 to 8.1 in both GR2 and GR3, while the peat-lite mix had a slightly acidic $\mathrm{pH}$ of 6.7 (Table 4 ).

GR2 had the highest EC (4.4 $\mathrm{mS} \cdot \mathrm{cm}^{-1}$ ) of any substrate tested, though no explanation why can be provided based on available data. Conductivity readings in the peat-lite mix were higher $\left(1.47 \mathrm{mS} \cdot \mathrm{cm}^{-1}\right)$ than other green roof substrates $(0.56,0.37$, and $0.34 \mathrm{mS} \cdot \mathrm{cm}^{-1}$ in GR4, GRl, and GR3, respectively) (Table 4 ).

SEed Germination. Across all substrates, the germination of pinto bean seeds was significantly higher $(76.2 \%)$ than that of indian blanket (43.4\%), yarrow $(40.4 \%)$, and shasta daisy $(23 \%)$ (Table 5 ). Shasta daisy was the poorest performer and had germination percentages below 50 in all substrates. Shasta daisy performed particularly poorly in the green roof substrates, as germination decreased by more than $30 \%$ in green roof substrates, as compared with the peat-lite control.

Germination rate did not differ between green roof and the peat-lite substrates, as maximum germination of all species appeared by day 21. Patterns were similar for all species, though the higher germination rate of pinto bean was easily seen at each recording interval in both the peat-lite (Fig. 1) and green roof mixes (Fig. 2). Also, no differences were found concerning germination rate, as all species attained maximum germination at day 21 , regardless of substrates type (Figs. 1-6).

Of special note is the very high SE with shasta daisy in GRl (Fig. 3). Maximum germination of shasta daisy in GRl ranged from a high of $40 \%$ to a low of $8 \%$ at day 28 . This is the only substrates, other than the peat-lite mix, in which shasta daisy had even a single record of a germination percentage of 40 or higher. This demonstrates a potential for higher germination, but an inability of the substrates to provide consistent conditions for seed germination.
Seed Size AND Germination. Pinto bean was the largest seed of all, including fewest seeds per gram (2.6 seeds $/ \mathrm{g})$, seed length $(12.9 \mathrm{~mm})$, seed width $(8.2 \mathrm{~mm})$, and seed area $\left(105.8 \mathrm{~mm}^{2}\right)$ (seed length $\times$ seed width) (Table 6). Yarrow had the most

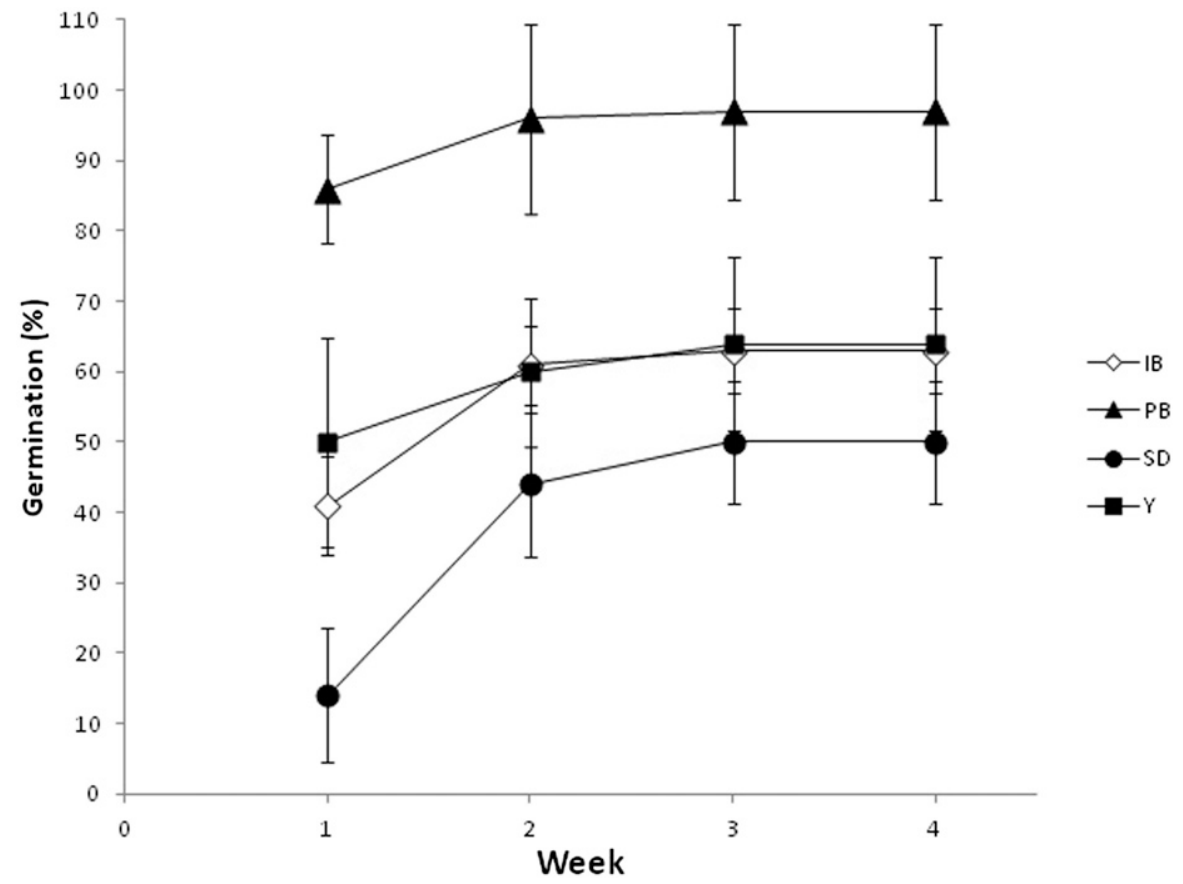

Fig. 1. Trial comparing seed germination of pinto bean (PB), shasta daisy (SD), yarrow $(\mathrm{Y})$, and indian blanket (IB) in a peat-lite substrate (BM6; Berger Horticultural Products, Saint-Modeste, Quebec, Canada). Bars represent SE.

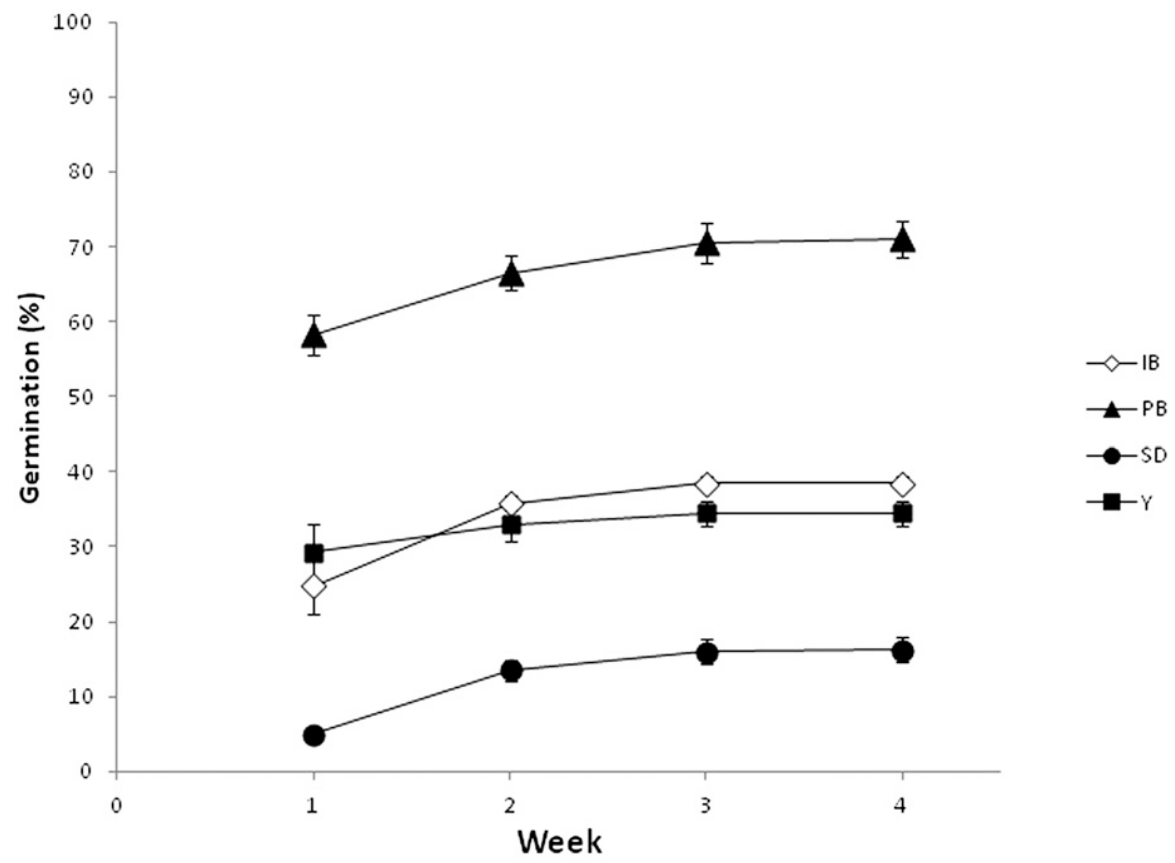

Fig. 2. Trial comparing seed germination of pinto bean (PB), shasta daisy (SD), yarrow (Y), and indian blanket (IB) in four commercially available green roof substrates. Bars represent SE. 


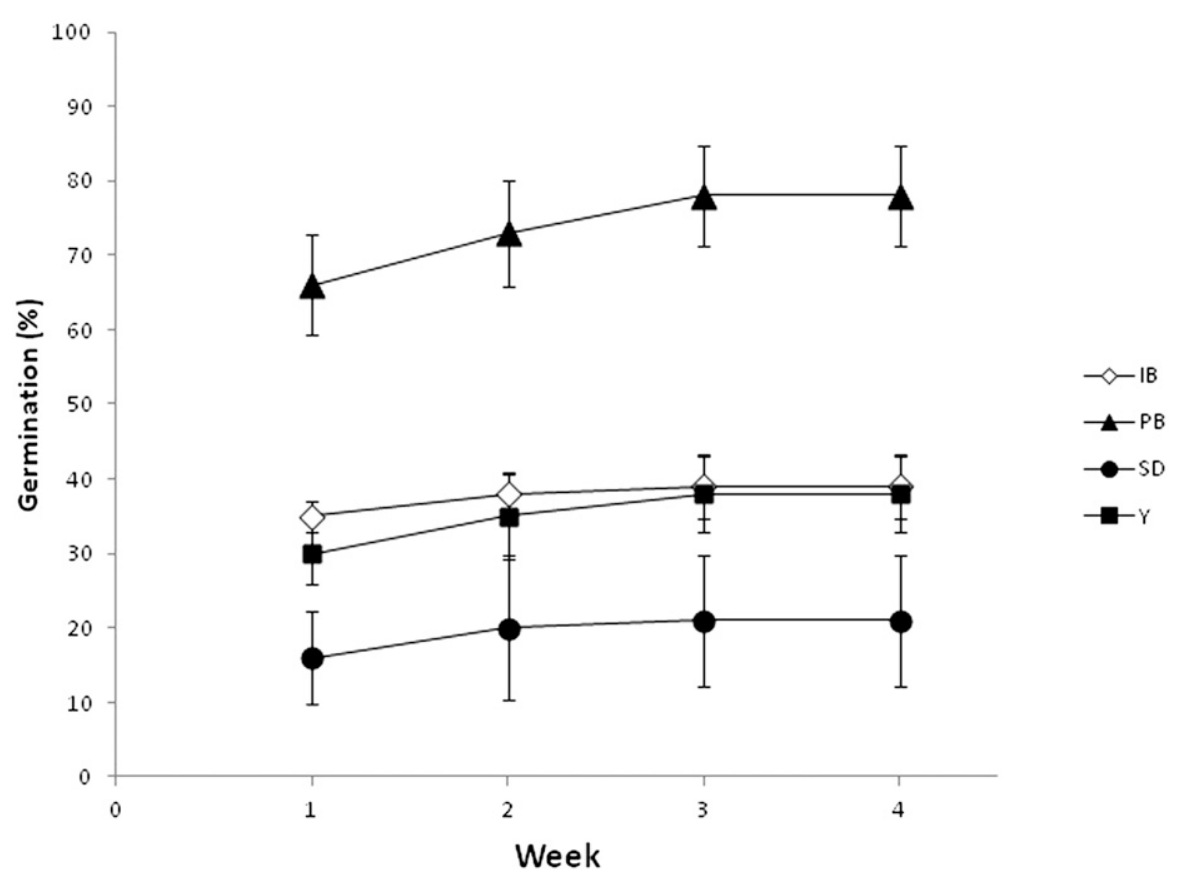

Fig. 3. Trial comparing average germination of pinto bean (PB), shasta daisy (SD), yarrow (Y), and indian blanket (IB) in a commercially available, expanded shale, perlite, and peat green roof mix (GreenGrid; Weston Industries, Chicago, IL). Bars represent $\mathrm{SE}$.



Fig. 4. Trial comparing average germination of pinto bean (PB), shasta daisy (SD), yarrow (Y), and indian blanket (IB) in a commercially available, expanded shale and compost green roof mix (Soil Building Systems, Dallas, TX). Bars represent SE.

seeds per gram (6000 seeds/g), while shasta daisy and indian blanket were more intermediate (917 and 330 seeds/g, respectively). Seeds per gram was not correlated with seed germination, but very strong correlations were found between germination and seed length correlated $(r=0.49, P=0.03)$ with seed germination. Because WFP must be small enough $(<416 \mu \mathrm{m})$ to hold water against the force of gravity (Drzal et al., 1999), the relatively low percentages of WFP $(<45 \%)$ ( Table 3 ) of the green roof substrates is indicative of an abundance of macropores.

Germination and $\mathrm{PH} / \mathrm{EC}$. Green roof substrates had significantly higher $\mathrm{pH}$ than the compared peat-lite substrate (Table 4 ), with all green roof substrates being slightly alkaline $(\mathrm{pH} 7.8-8.1)$ and the peatlite substrate being slightly acidic. Though considerably different, the correlation between seed germination and $\mathrm{pH}$ was quite high $(r=-0.52$, $P=0.02$ ). However, this relationship is more likely related to other substrate characteristics, as the $\mathrm{pH}$ of green roof substrates was similar, but differed significantly from the peat-lite substrate.

All green roof substrates, except for GR2, had EC readings lower than the peat-lite substrate (1.47). The EC in the peat-lite substrate was likely due to the presence of starter fertilizers and limestone added to raise substrate $\mathrm{pH}$. The GR2 substrate had the highest $\mathrm{EC}\left(4.44 \mathrm{mS} \cdot \mathrm{cm}^{-1}\right)$ of all substrates tested, though the reason for the elevated EC was unclear. Although variation in EC existed, no correlation between EC and germination success could be established $(r<-0.01)$.

\section{Discussion}

The use of green roof substrates negatively affected germination of all species tested, including the very large seeded pinto beans used as the control. Although no direct causality can be established, a strong relationship between seed size and germination performance was noted, implying a decrease in seed germination related to green roof substrate pore size. Given the coarseness of the green roof substrates, it is reasonable to assume that the effect of seed size would be magnified.

The physical characteristics of green roof substrates are necessary to prevent the retention of excess water, which adds additional weight, possibly exceeding roof load capacity (Ampim et al., 2010). The substrates are designed to retain sufficient moisture for plant growth, but appear to 


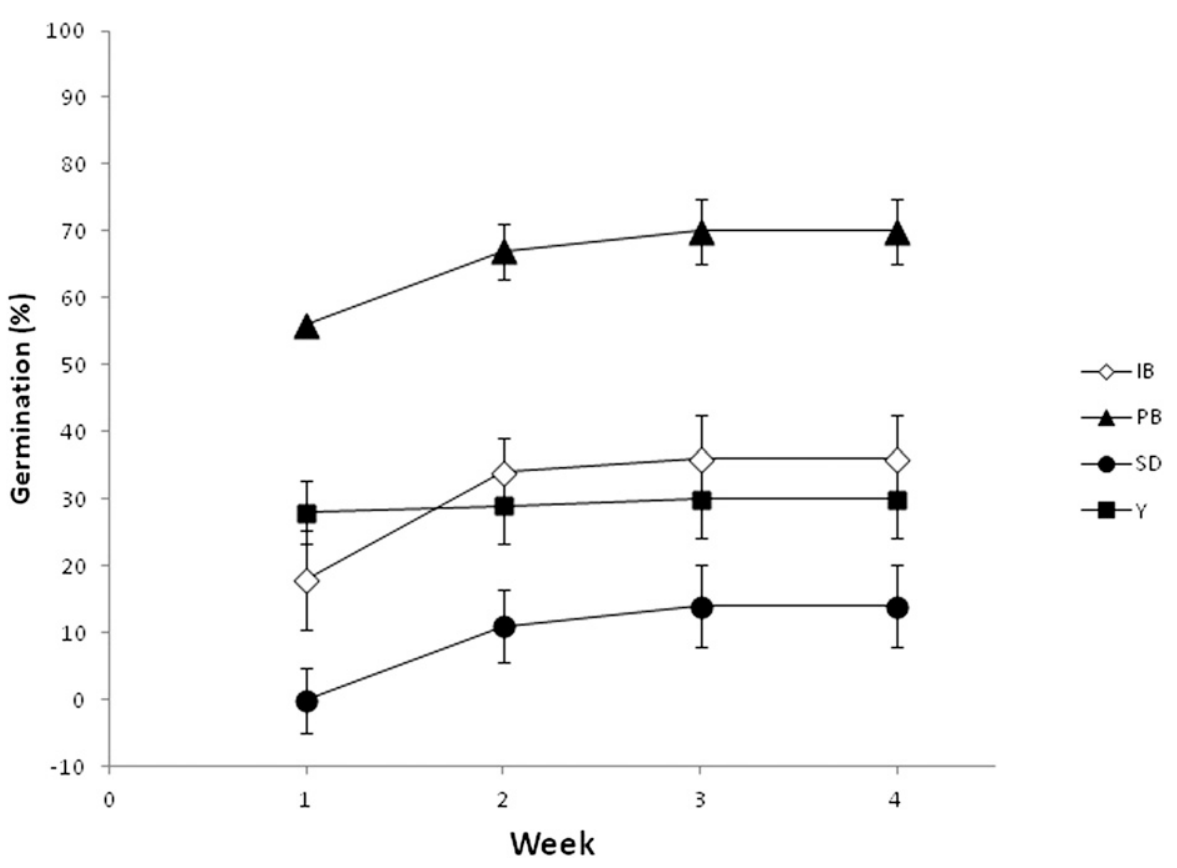

Fig. 5. Trial comparing average germination of pinto bean (PB), shasta daisy (SD), yarrow (Y), and indian blanket (IB) in an experimental, expanded shale and black dirt green roof mix (Soil Building Systems, Dallas, TX). Bars represent SE.

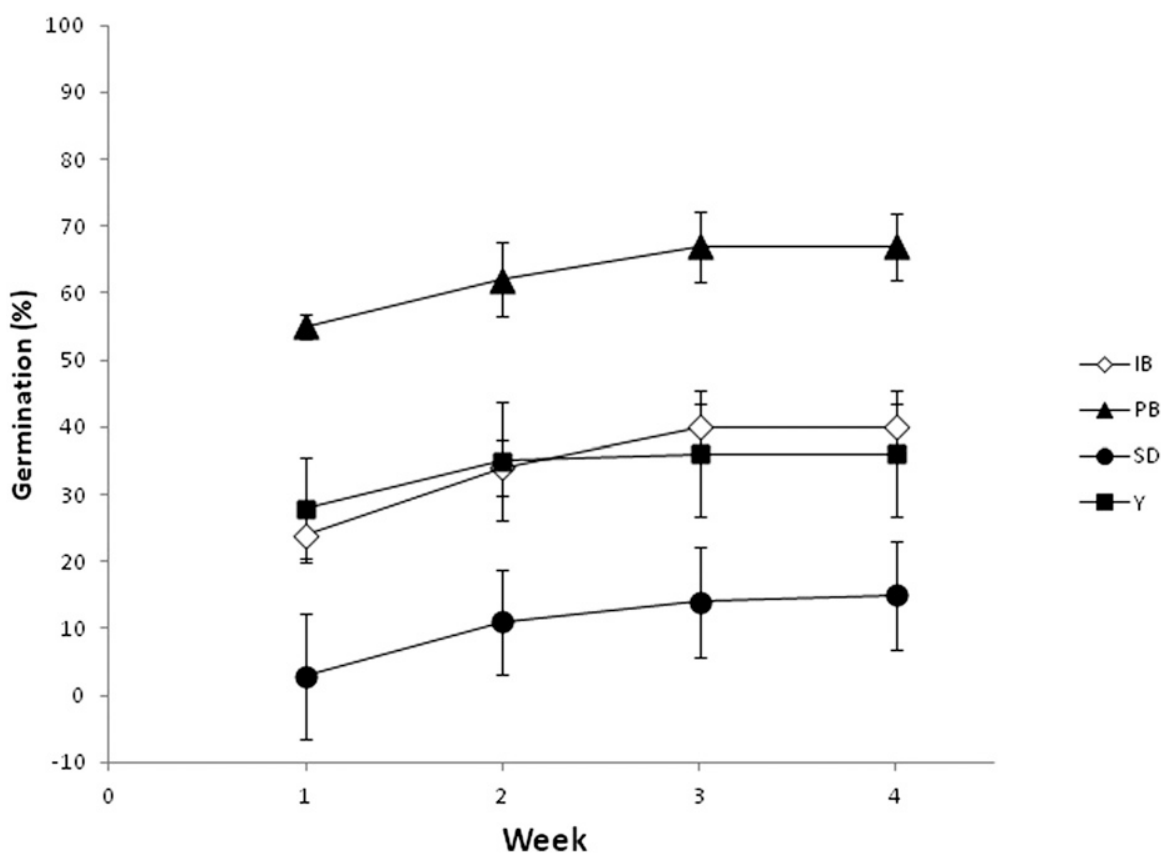

Fig. 6. Trial comparing average germination of pinto bean (PB), shasta daisy (SD), yarrow (Y), and indian blanket (IB) in a commercially available, expanded shale and compost green roof mix (RoofLite Extensive Green Roof mix; Landscapers Pride, New Waverly, TX). Bars represent SE.

Table 6. Seed size of pinto bean, shasta daisy, yarrow, and indian blanket. Seed length and width determined as an average of five seeds per species.

\begin{tabular}{lcccr}
\hline Species & $\begin{array}{c}\text { Seeds } \\
\mathbf{n o .} / \mathbf{g}^{\mathbf{z}}\end{array}$ & $\begin{array}{c}\text { Seed length } \\
(\mathbf{m m})^{\mathbf{z}}\end{array}$ & $\begin{array}{c}\text { Seed width } \\
(\mathbf{m m})\end{array}$ & $\begin{array}{r}\text { Seed area } \\
\left(\mathbf{m m}^{\mathbf{2}}\right)^{\mathbf{z}}\end{array}$ \\
\hline Pinto bean & 2.6 & 12.9 & 8.2 & 105.80 \\
Shasta daisy & 917 & 3.4 & 1.3 & 4.42 \\
Yarrow & 6000 & 2.6 & 0.6 & 1.56 \\
Indian blanket & 330 & 2.6 & 1.9 & 4.94 \\
\hline
\end{tabular}

${ }^{2} 1$ seed $/ \mathrm{g}=28.3495$ seeds $/ \mathrm{oz} ; 1 \mathrm{~mm}=0.0394$ inch; $1 \mathrm{~mm}^{2}=0.0016$ inch $^{2}$. be poorly suited for seed germination, findings consistent with those of Ksiasek et al. (2014) and McDavid (2012). Even short-term dehydration, which would occur in the large, open pore spaces of green roof substrates, may be fatal for the germinating seed (Drzal et al., 1999).

Since this study was conducted in a greenhouse, it is reasonable to believe that germination results on a green roof, with the additional variables of desiccating wind, predation by birds and/or insects, large diurnal swings in substrates temperature, and decreased relative humidity, germination would be even lower than reported here. Therefore, the need exists for alternative, but temporary, materials that maximize the seed:soil interface and optimize the germination environment.

Short-term substrate components, such as fine compost or peat, could provide a good seed bed, but eliminated via leaching during irrigation or natural precipitation. Hydromulch was proven to have reasonable success with seeds from various species of stonecrop (McDavid, 2012), and it could be tested on a wider range of species in a variety of locales. Another option would be the exploration of seed coatings or seed priming techniques that provide sufficient moisture to ensure seedling root development and plant survival. Because seed remains the most efficient and inexpensive means of plant establishment, identification of an effective seeding technique could help decrease the cost of green roof plantings and, in turn, result in a broader implementation of the technology.

\section{Literature cited}

Ampim, P., J. Sloan, R. Cabrera, D. Harp, and F. Jaber. 2010. Green roof growing substrates: Types, ingredients, composition and properties. J. Environ. Hort. 28:244-252.

Castleton, H.F., V. Stovin, S.B.M. Beck, and J.B. Davidson. 2010. Green roofs: Building energy savings and the potential for retrofit. Energy Build. 42:1582-1591.

Drzal, M.S., W.C. Fonteno, and D.K. Cassel. 1999. Pore fraction analysis: A new tool for substrate testing. Acta Hort. 238:67-74

Fonteno, W.C. and C.T. Harden. 2003. Procedures for determining physical properties of horticultural substrates using the NCSU porometer. Horticultural 
Substrates Laboratory, North Carolina State Univ., Raleigh.

Getter, K.L. and D.B. Rowe. 2006. The role of green roofs in sustainable development. HortScience 41:1276-1285.

Harp, D.A., R.I. Cabrera, W.A. Mackay, J.J. Sloan, and M.A. Arnold. 2008. Preliminary evaluation of open-cell foam for extensive green roof systems in Texas. HortScience 43:613 (abstr.).

Harp, D.A. and C. Dunlap. 2012. Thermal performance of green roofs in Texas. Proc. Southern Nursery Assn. Res. Conf. 56:212-215.

Hopman, D. 2011. The University of Texas at Arlington extensive green roof. 5 Jan. 2015. <http://www.uta.edu/ sustainability/_downloads/Green $\%$ 20Roof\%20Report.pdf>.

Ksiasek, K., J. Fant, and K. Skogen. 2014. Native forbs produce high quality seeds on Chicago green roofs. J. Living Architecture 2:e2.

Liu, K. and J. Minor. 2005. Performance evaluation of an extensive green roof. Proc. 3rd North Amer. Green Roof Conf.: Greening rooftops for sustainable communities. Cardinal Group, Toronto, Canada. p. 1-11.

McDavid, K.L. 2012. Utilizing sedum seeds as an installation method for green roofs through seed enhancement techniques. Pennsylvania State Univ., University Park, PhD Diss.
MacIvor, J.S. and J. Lundholm. 2011 Performance evaluation of native plants suited to extensive green roof conditions in a maritime climate. Ecol. Eng. 37:407-417.

Nelson, P.V. 2003. Greenhouse operations and management. 6th ed. PrenticeHall, Upper Saddle River, NJ.

Niachou, A., K. Papakonstantinou, M. Santamouris, A. Tsangrassoulis, and G. Mihalakakou. 2001. Analysis of the green roof thermal properties and investigation of its energy performance. Energy Build. 33:719-729.

Oberndorfer, E., J. Lundholm, B. Bass, R.R. Coffman, and H. Doshi. 2007. Green roofs as urban ecosystems: Ecological structures, functions, and services. Bioscience 57:823-833.

Olszewski, M.W., M.H. Holmes, and C.A. Young. 2010. Assessment of physical properties and stonecrop growth in green roof substrates amended with compost and hydrogel. HortTechnology 20:438444.

Santamouris, M., C. Pavlou, P. Doukas, G. Mihalakakou, A. Synnefa, A. Hatzibiros, and P. Patargias. 2007. Investigating and analyzing the energy and environmental performance of an experimental green roof system installed in a nursery school building in Athens, Greece. Energy 32:1781-1788.
Sutton, R.K. 2013. Seeding green roofs with native grasses. J. Living Architecture 1:el.

U.S. Department of Agriculture. 2005. Seedbed preparation and seed to soil contact. Plant Materials - 6. U.S. Dept. Agr., Natural Resource Conservation Serv. Tech. Notes. Spokane, WA.

U.S. Environmental Protection Agency. 2008. Reducing urban heat islands: Compendium of strategies green roofs. U.S. Environ. Protection Agency, Washington, DC.

Voyde, E., E. Fassman, R. Simcock, and J. Wells. 2010. Quantifying evapotranspiration rates for New Zealand green roofs. J. Hydrol. Eng. 15:395-403.

Wright, R.D. 1986. The pour-through nutrient extraction procedure. HortScience 21:227-229.

Young, T., D.D. Cameron, J. Sorrill, T. Edwards, and G.K. Phoenix. 2014. Importance of different components of green roof substrate on plant growth and physiological performance. Urban For. Urban Green. 13:507-516. 